\title{
Animation, the Cat, and Escaping Drawing
}

\author{
Sarah Treadwell and Paul Veart
}

I. Released in the same year as The Matrix: Reloaded, the second part of the Matrix trilogy, The Animatrix was released direct to video/DVD (after a brief cinema release). The nine animations have seven different directors, mostly from the Japanese animation industry. The animation Beyond is directed by Koji Morimoto.
In her essay "Without End, no, State of Drawingness, no, rather: The Executioner's taking off", Hélène Cixous has an explicit and unusual account of drawing:

The drawing is without a stop. I mean to say the true drawing, the living one-because there are dead ones, drawn-deads. Look and you shall see. Barely traced-the true drawing escapes. Rends the limit. Snorts. Like the world, which is only a perennial movement, the drawing goes along, befuddled and staggering, with a natural drunkenness. (Cixous, 1998c: 21)

Cixous raises the possibility that not only might human beings be rent with a shifting animal/human divide, but that drawings too might slip across categorical boundaries that regularly shape knowledge of life and its effects. Drawings, already meshed and riven in terms of technique and content, might also be quickened with the active involvement of time and spatial sequence. In her depiction of drawing Cixous imagines drunken, disruptive movement that is variably paced and unpredictable. Drawing that eludes finish and that seeks passing truth through encounters with error is what interests Cixous; drawings on the run with erratic speed.

For Cixous, Blythe and Sellers suggest, the "practice of working on what moves, on what escapes" is something that "can only be done poetically" (Blythe \& Sellers, 2004: 92). Poetic work means allowing for a certain degree of freedom in interpretation-looking for potential for things (words, phrases, drawings) to mean more than their first appearance suggests. In this vein this paper sets a short animation, Beyond ${ }^{1}$ by Koji Morimoto, alongside the poetic practice of Cixous. Her words are arranged in terms of a perceived correspondence through proximity, as found in the alongside-ness of children's play (an implicit theme of the animation). The adjacency is imagined as a spatial and interpretative potential with animal connections-heightened senses and peripheral vision.

Beyond is one of a compilation of nine animated films titled The Animatrix, a joint Japanese-American production that is part of the Wachowski brothers' multi-media approach to the world of the Matrix. The protagonist of Beyond is a young woman called Yoko who lives alone with her cat, Yuki, in a small apartment in urban Kichijoji, Japan. Yoko seems to be a typical anime orphan; she searches for a lost cat that is her main source of emotional expression (and the only creature that seems aware of the Matrix). Following some children to an abandoned site with a haunted house, she finds her cat (and herself, in bliss) through an instability in the world. She and the children are eventually evicted from the site, which is then sealed and remade as a parking lot. 


\section{Drawing contours}

Not all animations constitute 'escaping texts' despite the literal, constructed movement in the drawing. Some animators draw cartoon contours as closures, and never escape them. Cixous wants to draw that which is invisible to the naked eye and impossible to draw, "the quick of life" (Blythe \& Sellers, 2004: 25). She sees traces of the quick of life in a rounded appearance that necessarily conceals the lack of pity and the brilliance of horror in drawing.

The animation operating in Beyond sets up categories of life through conditions of drawing: categories that, however, leak and reverse. Certain things in the depicted city are drawn without contour and with attention to variations in surface condition, creating a reassuringly stable background-Cixous' rounded appearance. But while the drawing of the city tends to the realistic surface, with its technical assurance and consistency, it also becomes mere backdrop when set against an animated condition.

Things in the (insecure) animal category are drawn with a linear contour and flat colouration and include Yoko, a young girl/woman; Yuki the cat/girl; and a raven, a dove, and a dog. If cartoon drawing is reserved for the animated as a category of the living, then it also spreads into categories that are close to or touch the living: the cat's feeding bowl and Yoko's bed are drawn with pronounced contour. Contour drawing extends the corporeal, even as it fashions it with a line that is removed from depictions of reality, a line that proclaims most clearly its constructed nature.

The film is structured by a line, a linear narrative, which, however, returns. The story starts with a city scene; depressed looking people march across an intersection. A curious melody plays, a refrain, signalling a marking of territory and imminent change. The sound is plaintive and reminiscent of childhood, haunting and repetitive. ${ }^{2}$ Another road intersection follows, with the same song, but this time it is empty. The refrain hangs as a faint echo in the air. A crow or raven flies into the intersection; in its blackness, and with its melancholic cry, it intimates doubt or tragedy. The cat, Yuki, strolling into the intersection, scares the bird away.

Cixous uses an image of something breathing under the pen that writes and draws: a beak/pen that sings, eats, pecks and is both a weapon and an instrument. A bird that can be scared away in the combat that is her image of drawing (Cixous, 1998c: 21).

\section{Cats and shadows}

Purposefully walking across the square the escaping cat, Yuki, wears a bell (suppression of feral hunting) and is well fed. It also has what could be the mark of a human footprint patterning its body (as a human might wear leopard fur, so the cat's coat is decorated). Yuki, strolling along a wall, purrs until, behind the wall, it sees its own impossibly large shadow projected onto a building. The disconcerting suggestion of a gigantic cat is caused by familiar techniques of architectural drawing - manipulations of scale, skiagraphy and controlling projections.

Cats in the eighteenth century were positioned as moral monsters in that they, like children, represented the asocial. As James Steintrager points out, "cats are the spectre of society's dissolution" (Steintrager, 2004: 37). The curiosity of Yuki the cat leads Yoko to a place that is outside society and
2. The tune is the Japanese folksong "Tohryanse", which contains a metaphor not dissimilar to that of The Matrix. This is the concept of the chosen one, such as $\mathrm{Neo}$ and Yoko, who have the potential to discover the 'real world'. 
in which play rather than law is operative. The curious cat remains potentially the cruel hunter in that it scares the crow and later hunts the white dove associated with transformative pleasure and excess.

In the story "Shared at Dawn" Cixous writes of finding a dead bird caught in a trellis in her house, only to discover that it was still alive and sought by her cat. Instinctively she released the bird to the despair of her cat, who sought the bird in the house long after its departure to the other side of the city. Cixous regretted her action:

I've betrayed my counterpart, my betrothed, my little bride with the boundless heart; oh my god if that bird comes back I will give it to her I swear-yes it is better that I swear, surer that way, yes, if it came back, I too would play with its lukewarm little body, I'd give it sharp little blows with my paw and I'd slit its throat cheerfully. (Cixous, 1998a: 179)

Cixous momentarily lets the cat in herself surface as she deals with the bird. Invoking the law she swears to sanction her own cat-like desires. Cixous sees relationships between animals and humans in metaphorical, dream-like terms:

Animals are important for me because I can't imagine human beings other than as animals in transition ... I need the instinctiveness and the wildness in a human being. So when I meet people in reality, or in dreams, there's always a kind of animal awake in the person. (Quoted in Blythe \& Sellers, 2004: 64)

Drawings, too, are part of the instinctive wildness of the animal, but they are socially conditioned and claimed as combatative. Cixous writes: "... every drawing (is) combat(s) itself. Drawing is the emblem of all our hidden, intestine combats" (Cixous, 1998c: 28). In Beyond appetites, senses and instincts are represented, constructed and unknowable.

Yoko, in her apartment, talks on the phone and simultaneously gets food ready for her cat. Yoko is ambiguously child and adult: she lives alone and is responsible for her cat; its physical necessities are a proof of life. Yoko herself is drawn with her body rotating across and around the bed as she chats and looks for her cat simultaneously. Her movements are sinuous and unselfconscious; cat-like, she seems to lack bones.

From her carefully rendered apartment Yoko hears, unnaturally acutely, the sound of her cat's bell in the city into which she descends. The spatial nature of sound is aligned to filmic technique; there is a sudden blackness signalling the erasure of the visual world in the speed of movement. A heightened sense of animal hearing momentarily predominates. Cixous writes with her senses: "by apprehension, with noncomprehension, the night vibrates, I see it with my ears ..." (Cixous, 1998c: 29)

After enquiring as to the whereabouts of her cat from neighbours, Yoko is told by a boy that her cat is at a haunted house. Yoko and the children stand on a chain mesh fence and look across the city to the distant site of the house that is marked by a rainbow. 


\section{Dogs, butterflies and the haunted house}

The film then cuts to the city, where a woman attempts to control a leashed dog as it slavers and barks at the approach of a menacing looking truck. The dog is wild with fear and the woman who holds him seems anxious. Dogs, once wolves, are nervously presumed to be domesticated. In Beyond the leashed dog intimates imminent alteration; it barks at that which will eventually destroy paradise. To draw is not to be domesticated, according to Cixous: like the frantic dog that senses destruction, so too painters might draw because "drawing is the right to tumult, to frenzy" (Cixous, 1998c: 29).

Yoko walks towards the barricaded haunted house. It is not a singular house but, rather, a conglomeration of variable structures. She enters the decaying interior that opens into a courtyard and sees a can floating just above the ground. Around it golden butterflies play. Even while the tin floats above the ground it is still subject to gravity that holds it aloft while the butterflies move lightly in three dimensions and, in their animation, actively resist gravity. ${ }^{3}$

For Cixous the relationship between ground and foot, a relationship of gravity, is uncertain: she cannot find firm footing: "Graze the paper with the soul's foot, and immediately the foot slips" (Cixous, 1998c: 29). She writes of an agitation that reigns in drawing-drawing as essay, as trial; the butterflies in Beyond point to the provisional nature of the tin's suspension, and the certainty of its fall.

The haunted house in the animation is internally labyrinthine: rather than being a discrete object, it is riven with internal openings. The house has at its (multiple) heart a leak; rain falls in from a broken roof. Mark Cousins has written of the horror that a leaking roof provokes with its undermining of house/body security (Cousins, 1992-3: 37). ${ }^{4}$ But the internal cascade in Beyond has the opposite effect: gleaming trajectories of water make small bell-like noises and cast prismatic light as a halo; the leak is portrayed as wondrous. For Cixous, far from being damaging, the leak that shimmers, the error in construction, is to be sought: "... to what extent we can't do without the silvery burst of error, which is the sign, [like a rainbow] all those who go by pen don't cease to marvel at this in a similar way, from century to century" (Cixous, 1998c: 22).

Feral processes flourish in the haunted house in Beyond. Yoko discovers a dog ravenously eating, and as it eats colour surges through its body. The drawing contours of the dog that indicate both animation and the fabricated aspect of the creature will be obliterated by a colour that becomes coded as evidence of life: food malevolently flushes the body with blackness. The linear drawing that signals drawing-as-animated, and drawing coded as not real, in this scene, becomes invested with drives, with temperament. The dog stares at Yoko, who backs away. Its eyes are red, filled with the blood that will later leak from Yoko.

Hélène Cixous' story "Stigmata, or Job the dog" (1998b) is sited in Algeria after her father died, between the abject misery of an Arab quarter and a French neighbourhood. The dog Fips that she "loved by force, according to the laws of captivity" (Cixous, 1998b: 190) is driven mad by stone-throwing attacks on the house that occurred after the loss of her father's protection.
3. The ubiquitous tin can reappears at the end of the film when it is kicked by the cleanup agents, when it cuts Yoko's finger and she bleeds and, in the end, when it is claimed by gravity. The tin projects back to the viewer evidence of everydayness even in the marginal world

4. Thanks to Rachel Carley for bringing this to my attention. 
We put the dog on a leash and tied the leash to a wire and the wire to an iron posts so he would not kill, we ourselves chained up our own incarceration, we ourselves put my father's heir in irons. (Cixous, 1998b: 190)

The situation worsens with the child Cixous being bitten and the dog eventually dying. Cixous writes:

I should have spoken to him, I should have, if I had been able to understand him but I thought him perhaps incapable of understanding for I was not then capable of understanding the profound animal humanity... . (Cixous, 1998b: 190)

In her story Cixous suggests that time was the problem: time, disjunctions and anachronisms; there was no time. The starving dog that wolfs down some undesirable food (drawn but barely there) seems to be making up for lost time, in its desperation evidence of some sort of failure in sustenance. Cixous writes, "What remains of a sheet of paper becomes a field of battle on which we, writing, drawing, have killed each other ourselves. A flagstone of paper under which a carnage effaces itself" (Cixous, 1998c: 28).

\section{Animated house, surface and ground}

While the dog flushes with blackness the sound of crackling electricity indicates an anomaly in the house. A broken light bulb completes itself momentarily and the filament glows. As the electrical pulse fades the light dims and the broken bulb reappears. Electricity, as a form of nerve-signal, pulses intermittently through the body of the house, the same electrical current that Cixous finds between the viewer and drawings that seek the living of life (Cixous, 1998c: 26).

Yoko goes into a dark corridor and, hearing a noise behind her, turns and sees the walls of the corridor delaminate. The pieces of wall (paper) hit her like bats. The unnerving effect extends to the floor on which Yoko sits. Both Yoko and the pieces of wall are made with the same drawing processes; they share the space of house and screen. The screen itself seems to digitally break down and pixilate as the papers sweep along. The sharp speed of the disintegrating walls is confirmation of Cixous' suggestion that "acceleration is one of the tricks of intimidation" (quoted in Bray, 2004: 144).

Conventional haunted house movies rely on a readily acceptable belief that spaces are emotionally charged by events that might be explained by a projection of memories and feelings. But in Beyond, rather than being simply alive or subject to projection, the house is undoing, shredding. Walls as rendered background (familiar, rounded) have become delineated, sharp pieces of drawing that move as a "death passing" (Cixous, 1998c: 27).

Ground that, in the dark corridor, was unstable with earthquake effects is, in the next sequence, doubled; an old pavement marked with an arrow is repeated and rotated. On this surface Yoko picks up and cuddles Yuki, who unexpectedly growls like a very large tiger. On the doubled ground the cat plays with Yoko's detached shadow and a small girl, who may be Yoko herself at another time, plays alongside. Shadows may be dark death marks that cannot be illuminated but here carry the human/inhuman interface 
lightly, playfully. An interface that outlaws categorical purity for Cixous who leaves "nothing of ... pre-classifications intact" (Cixous \& Calle-Gruber, 1997: 151).

\section{Feathers, birds and bliss}

Children in the haunted house play with gravity, making and unmaking a glass bottle. They dive towards the ground and stop, poised above it as the tracking camera plunges with them. Despite the apparent lack of impact a nose bleeds. Yoko joins the children, as does a white dove. A feather hypnotically rotates before Yoko: she holds it briefly. At the same moment the cat chases the dove, which flies up in front of Yoko. Time suddenly slows down and the bird is pictured as it laboriously climbs into the air. Whiteness descends and touches Yoko, who falls sideways. Slowly and gently she lands, blissful pleasure evident; the viewer shares her spatial alignment.

In the story "Writing Blind", Cixous writes:

We all like to be to touch-to be touched. ... It is with emotion and nostalgia that I touch the soft and ferocious touch of my cat [mon chat ma chatte], the cat whose cat I am, and between us no appropriation only moments of grace, without guarantee, without security without a glance thrown towards the following moment. This is jouissance. All now. (Cixous, 1998d: 142)

For Cixous drawing is not necessarily a visual act: "The drawing wants to draw what is invisible to the naked eye" (Cixous, 1998c: 24). Rather than proposing drawing as simply haptic it seems that, like the touch of cat's fur on the back of the legs, drawing is an internal blind exploration-a moment of sympathetic felicity. Cixous draws in darkness and sees what is drawn in the light of day, but the white fog in Beyond is a palpable light that touches but doesn't reveal.

Yoko knocks gently on the earth: "Is anyone home?" To knock on the earth is to be a stranger who imagines the possibilities of homeliness. To be shut out, to live for the moment, is, however, pleasurable. "All now", Yoko smiles. Jouissance is often figured as a sort of speed, an "ecstatic flash of new meaning" (Bray, 2004: 144). But for Cixous speed is the antithesis of non-dominative thinking; Yoko falls slowly into pleasure. Speed returns in the film with the arrival of an extermination truck.

In horror movies, bliss (especially sexual pleasure) is often followed by death, but in this case it induces play. Yoko and the children, in the vertical space of the courtyard, joyfully explore time and gentle gravity. Yoko falls in slow motion towards the earth and a small boy catches her by the heel: "light as a feather". Girl becomes woman, cat, bird, feather in a stream of shifty alteration.

It is at this point of pure play, a condition outside economies of production or definition through use-value, that an external observation obtrudes. The ground, on which Yoko lay in bliss, looks up at the scene with a low angle fish eye. Yuki peers into the hole, and a rat leaps out. The stream of rats that then leave the area are a warning: the ship is sinking; floating is no longer an option. 
Following the sound of her disappearing cat's bell, Yoko finds Yuki scratching at a red door. Holding the cat, Yoko looks into the space beyond the door: there is only blackness. Cixous describes drawing as a seeking in the dark-a never finished searching that is not directly answered but which provokes other 'secrets' to emerge. Sounds circulate in the blackness before Yoko, repetitions of her conversations, complicating linear time, activating ideas of surveillance.

\section{Reconfiguration: white, blue and red}

At this point Yoko and Yuki are caught in the spotlight of a torch wielded by a gas masked rubber clad figure barely discernible as human. "You don't belong here", he says, and drags her away. The city is invoked at this point-the crowded everyday life of a small street (where she presumably does belong), in opposition to the dark nothingness and white bliss of the house.

The forces of law, paternal prohibition, prevail with the children and Yoko being dragged out of the compound. Orders are given to seal off the area and this is achieved with pumped out whiteness. Is this the same whiteness that was associated with bliss, an act of obliteration casting bliss as the loss of self-definition in a merging that is also a forgetting?

The computer screen registers the effects of the house and site as a rendering anomaly and then records a 'reconfiguration' of the location. This is followed by a shot of blue sky which is also a blue screen with its tendencies to isolate and re-imagine context.

The haunted house has become a parking lot behind a mesh fence. The children, bored and sullen, try to activate the site but to no avail. Bottles smash and gravity works as usual. They depart sadly. Yoko standing at the perimeter of the remade site finds the tin can and picks it up-she too tests gravity and time. The can falls. Blood trickles from the cut it has made in Yoko's finger. It slowly winds down her hand and drips onto the stabilised facsimile of ground.

Cixous describes the search for that which it is desired to draw-"the quick of life" - as a series of approximations, something small and precise like a speck of blood, a nail, a needle-small sharp probes which damage. The quick of life, existing both prior and post vision as an apprehension or awareness, can only be approached cautiously, because with its visibility it will vanish.

Blood, the quick of life, which might stand as a proof of the body as an irreducible limit, a mark of biological origin, is problematised in this context. Yoko's body (that drips blood) refers to the computer-programmed bodies in the film The Matrix. In Beyond Yoko's body is a cartoon body, referring to a filmic body which represents a computer programmed body, and is physically drawn by hand from photographs of a young woman posed to anticipate the construction of the cartoon Yoko.

Yoko's fallen blood might also be a sign of a wounding. For Cixous the wound "is a strange thing: either I die, or a kind of work takes place ... It is here that I sense things taking place. The wound is also an alteration. ... I like the scar, the story" (Cixous \& Calle-Gruber, 1997: 16). In Beyond the wound, like stigmata, is a sign of both separation and repair. The story ends with a return to the beginning, a scene of city life in which depressed looking people march across an intersection. 
Filmmaker Morimoto was permitted to make an animation about everyday effects of the Matrix provided that the characters did not discover it. In Beyond, Yoko and the children do not even seek the reasons for the strange anomalies in their world; the cat Yuki who, being animal, was not hooked up to the Matrix (the law), but was part of the programme, was able to know about its presence. The cat as a systemic anomaly that didn't necessarily work to maintain the system could perceive and enjoy its representational effects: Yuki passed between systems.

Cixous refers to passwords (words that make passage between systems) as "magic animots", "animal-words", and registers a crossing between categories. The drawings that constitute the animation Beyond might be like Cixous' animots. They are of the everyday, fashioned by familiar techniques of animation, but in their representational complexity, in their unreliable categorization of life and the gravitational play that they both enact and picture, they seem to be drawings that cross the eyelid into the openness of the animal.

Wondering about people who seek finish, which she associates with the clean and the proper, Cixous poses a portrayal of truth in drawing that is characterised by a "panting and unstable allure"; drawing that looks to the drawing yet to be made; drawing that sees itself from a distance even as it is emerging.

Perhaps architectural animation needs to acquire such engaged distance, such animal allure, by losing the didactic and linear techniques which proposes architecture as self-evident, needing no telling, no bringing into the world. It might imagine instead a story like Beyond-a movie designed, shaped with responsive narratives-a hybrid design, part animal, that is a spatial making that casts genre, categories and orders into doubt. The director of Beyond, Koji Morimoto, certainly knew about categorical and temporal leakage: in a discussion on the making of the animation, he started by recounting a story from his childhood when he saw, on the surfaces of his home, the wood-grain move.

\section{References}

Bray, A. (2004). Hélène Cixous: Writing and sexual difference. Hampshire \& N.Y.: Palgrave Macmillan.

Blyth, I., \& Sellers, S. (2004). Hélène Cixous: Live theory. New York \& London: Continuum. Cixous, H. (1998a). Shared at dawn. In Stigmata: Escaping texts. London: Routledge.

Cixous, H. (1998b). Stigmata, or Job the dog. In Stigmata: Escaping texts. London: Routledge.

Cixous, H. (1998c). Without end, no, state of drawingness, no, rather: The executioner's taking off. In Stigmata: Escaping texts. London: Routledge.

Cixous, H. (1998d). Writing blind: Conversations with the donkey (E. Prenowitz, Trans.). In Stigmata: Escaping texts. London: Routledge.

Cixous, H. \& Calle-Gruber, M. (1997). Rootprints: Memory and life writing. London and N.Y.: Routledge.

Cousins, M. (1992-3). The First House. Arch-Text, vol. 1 (winter) 37.

Steintrager, J.A. (2004). Cruel delight: Enlightenment culture and the inhuman. Bloomington \& Indianapolis: Indiana University Press. 